\title{
SOCIAL CRM IN THE AIRLINE INDUSTRY
}

\author{
Jelena Gajić, \\ Radmila Živković, \\ Jelena Stanković, \\ Ivana Brdar
}

Singidunum University, Belgrade, Serbia

Correspondence: Ivana Brdar

e-mail:

ibrdar@singidunum.ac.rs

\begin{abstract}
:
The process of including the so called "digital" users who regularly express their attitudes and needs via social networks poses a huge challenge to modern airline companies. Given that the implementation of technological innovations enables identifying, developing and retaining high-end travelers, this paper deals with the analysis of benefits of business concepts proposed by airline companies based on high-technologies, primarily Social CRM (Social Customer Relationship Management - SCRM). The use of social media has altered the users' expectations, and enabled airline companies to more rapidly adapt to changeable expectations of travelers. The results indicate that the attitudes and comments of users, based on the use of SCRM on the Internet and social networks, have become instantly available to vast number of new users, thus forming the chain reaction that can have immediate positive or adverse effects on future business performances and positioning of airline companies in the market.
\end{abstract}

Keywords:

airline companies, profitable travellers, social CRM, Internet, loyalty.

\section{INTRODUCTION}

Modern information-communication technologies (ICT) have altered the principles of doing business and provided new and ground-breaking instruments that would enhance the global competitiveness (Tussyadiah \& Pesonen, 2016, p. 1). The attractiveness of digital space and virtual communication has posed significant challenges to the services sector, in particular tourism industry (Mastorakis et al., 2015; Živković et al., 2015). Contemporary tourists have at their disposal abundance of information on destinations, hotels, airline companies, prices, reservations, guest posts and reviews, and can instantly choose, purchase, travel, leave comments and gain unique travel experiences. Along with the latest technologies, new marketing trends have brought about numerous changes in the airline industry, by filling in the communication gaps using new methods of customer satisfaction measurement, collection of guest complaints and comments, provision of innovation etc. Marketing strategies are enriched with the new instruments for communication with service users, as well as suppliers, partners, employees (Mastorakis et al., 2015; Živković et al., 2015). Accordingly, the new area of Social Media Marketing has emerged, which manages the fast and multifaceted process of information transmission in various directions and towards different target groups, bearing 
in mind that the same message can have various meanings and leave quite different impressions, i.e. initiate diverse experiences.

The aim of the paper is to highlight the importance of Social CRM for airline companies, which use it to successfully upgrade the experiences of their travelers through new ideas, efficient solutions in the services sector and high-quality services.

\section{SOCIAL CRM IN THE AIRLINE INDUSTRY}

Information-communication technologies (ICT) have enabled airline companies to develop new strategic relationships with service users and establish the system that maintains long-term relationships, also known as CRM. Given that customer loyalty has become more important for increasing the market share and profitability (Neises, 2013, p. 7), airline companies seek to redirect the use of ICT in the area of electronic and digital communications (Mangold \& Faulds, 2009, p. 357; Mastorakis et al., 2015). This leads to the reduction of business costs, time optimization for performing the anticipated business activities, increasing employee efficiency, developing programmes for attracting potential travelers, personalization of services, and special loyalty programmes (Russo, 2011), with particular emphasis on providing more accessible services, and faster flow and exchange of information. Besides numerous advantages, this system has certain drawbacks that are mostly reflected in the security of e-payment of services, and credibility of the comments published on the web sites and social networks (Kekec \& Atay, 2012, p. 185). The developed countries have found more efficient methods to protect their users, while the devel- oping countries are gradually starting to implement the global communication trends, and thus are able to overcome such issues.

ICT provide tactical instruments for CRM development in the airline industry, and their aim is primarily to retain the most valuable customers. To that end, eCRM (Electronic Customer Relationship Management) and web technologies are used as a competitive business strategy to generate interactive relationships between airline companies and service users throughout all stages of the purchasing process (Milović, 2012, p. 25; Neises, 2013, p. 8; Mastorakis et al., 2015).

Airline companies invest enormous efforts into implementing the new systems that would ensure longterm customer loyalty, in particular those in the digital world. One such system is Social CRM, which implies that the company is capable of cooperating with service users relying on their needs and wishes, and not on its own rules and principles (Chess Media Group, 2010, p. 3). Social CRM implies active cooperation of all employees in the company and involvement in customer services, implementation of pull communication strategy with customers, 24/7 Internet access, use of various media for transmission of comments and complaints of users, as well as involvement of users in generating ideas to upgrade the overall quality of services Neises, 2013, p. 20; Biederman, 2008; Chaffey et al., 2006). Digital users born after the year 1980 are particularly relevant, as they mostly communicate via social networks (Mangold \& Faulds, 2009). They use the new social CRM to rapidly spread their opinions, which guarantees more intensive cooperation with the airline companies (Neises, 2013).

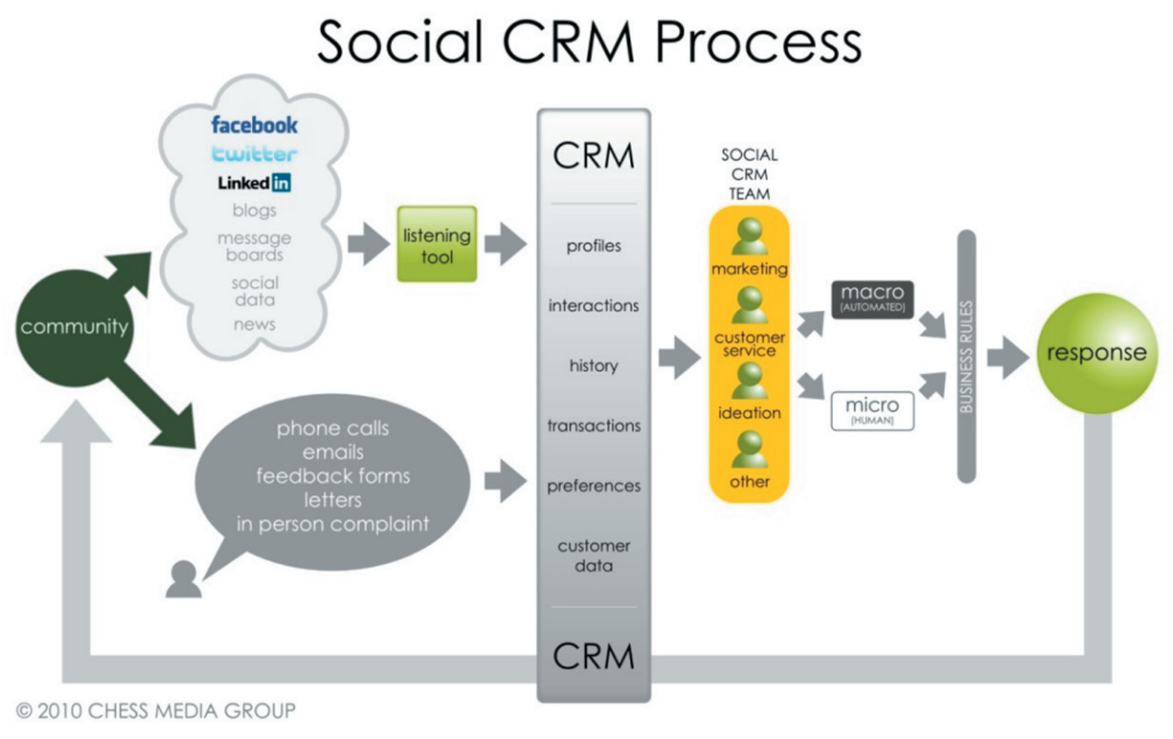

Figure 1. Proces Social CRM

Source: http://www.slideshare.net/fred.zimny/chess-media-group-guide-to-social-crm-2010 
SCRM process (see Figure 1) starts by collecting the comments and complaints of users, as well as creative employee ideas. This information serves as a basis for defining and selecting target groups and defining goals. The following step is to establish the so-called "community CRM employee teams", which deal with marketing activities, communication with users and customer service on the micro and macro level. Finally, the process of results measurement is performed, which needs to be in agreement with the predefined goals of the company. Specifically, social media activities, as well as the data on service users need to be incorporated into the CRM system and connected with the loyalty programmes, so as to lead social customer management to business outcomes (Morgan et al., 2011, p. 10; Mangola \& Faulds, 2009).

\section{SCRM IMPLEMENTATION}

There are various examples of airline companies that use SCRM to incessantly upgrade their offer and contents with the aim to retain their customers. For instance, Emirates continuously implement new services to develop relationships with customers, such as: adds augmented reality touch to its economy class amenity kits, pre-flight and in-flight entertainment. Namely, Dutch LCC Transavia was one of the first low-cost airline companies to introduce WhatsApp messaging for customer care, while Jetstar Asia introduced in-flight book exchange to encourage holiday reading.
Airline companies are introducing various innovative activities, such as gaming, customer participation in creating services and co-creation of tourist experience, so as to build long-term relationships with service users (Xu et al., 2015).

In order to surprise and motivate their travelers, KLM Airlines awarded personalized gifts to those who were waiting at Amsterdam Schiphol airport, on the basis of the personal data they left on Four Square and Twitter (e.g. their favorite activities and interests). The research has shown that the travelers were both surprised and pleased with such gesture (Morgan et al., 2011).

The survey of over 200 Twitter, Facebook and Instagram profiles of the 40 largest companies worldwide, which covered the period of three months, has shown that the use of eCRM and SCRM has brought about the following results to airline companies (Talkwalker, 2016):

- KLM is an airline company that most responds to the requests and comments of travellers on Twitter, up to $87 \%$ of requests, i.e., it delivers 118 responses on average per day;

- Twitter accounts of low-budget companies have the largest number of followers on Twitter, followed by Air Asia and Jet Blue;

- Quatar Airways has the largest number of Facebook fans;

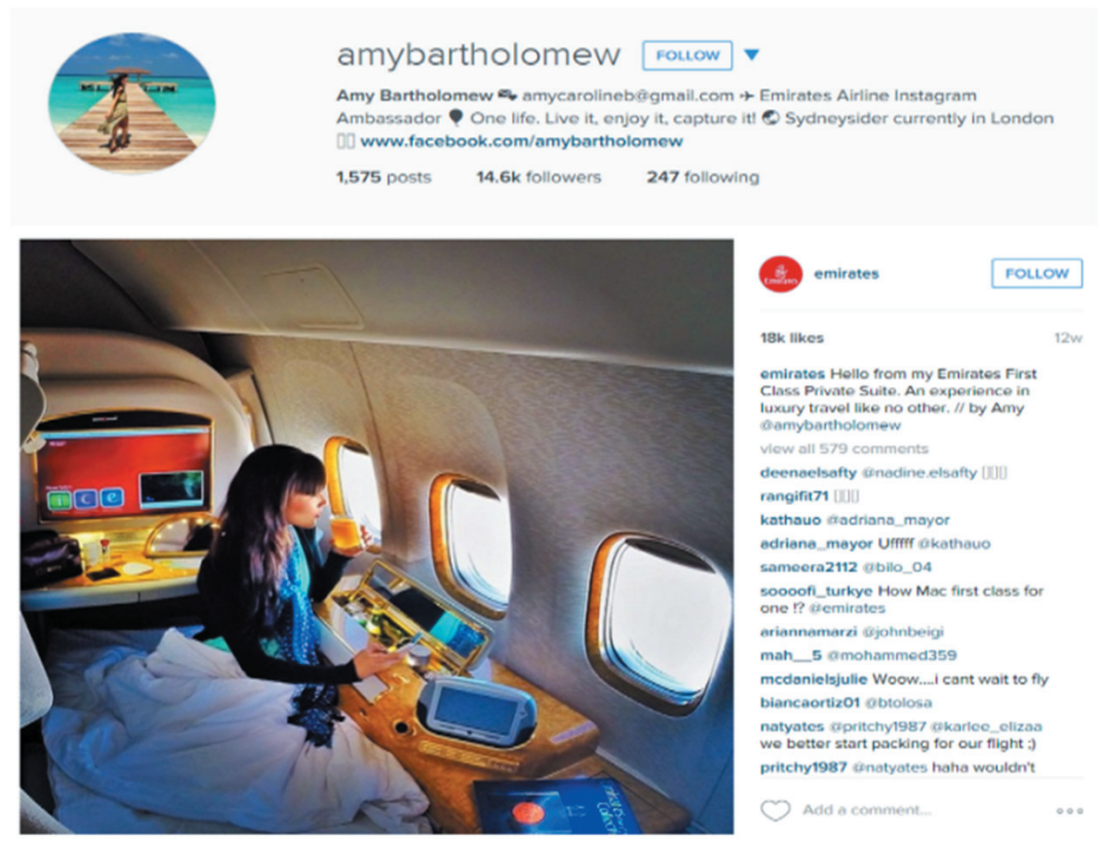

Figure 2. An example of a post on Instagram by "ambassadors" Emirates airlines Source: http://blog.talkwalker.com/en/top-40-airlines-social-media/ 
- Emirates and American Airlines are the most popular and widespread on Instagram.

Middle East airlines, including Quatar Airways, Emirates and Etihad, are also involved in the activities of generating posts of their travelers on the Internet. The results for the year 2015 show that Emirates and American Airlines are the most dominant on Instagram, i.e., Emirates are most often mentioned on Instagram worldwide, in Europe and Asia (Figure 2).

The airlines Emirates has developed one of the most efficient SCRM strategies based on the principle that the so called Instagram "ambassadors" of this airline company are actually its travelers who are active on Instagram, and the images of the company.

Continuous monitoring and analysis of social network benefits can provide the companies with the answers related to the efficiency of their SCRM strategies. We should bear in mind that everything that goes on the Internet, stays on the Internet. Thus, the results achieved by airline companies through implementation of their strategies via social media are of vital importance. This is also supported by numerous rankings of the most favourite and least favourite airline companies. Such rankings are based on the attitudes on service quality posted by both satisfied and dissatisfied travelers on social networks. According to one research, about 1.3 million tweets was analyzed during the holiday season for 70 world airline companies, so as to determine positive or negative feelings/experiences of travelers (Stratos Jet Charters, 2016). Given that all business organizations implement digital technologies and benefits of social networks, airline companies use Social Media Marketing to "monitor" their target groups. Numerous research has shown that social networks contribute considerably to more quality experiences of users with services and the company. Moreover, social networks strengthen the company's brands and enable users to express their opinion, measure their satisfaction, i.e. dissatisfaction, in a fast and efficient manner. A lot of recent studies, whose results serve for strengthening social media strategies, deal primarily with "linking brands" and digital users.

\section{CONCLUSION}

The potential of social media and networking is used as a vital part of all marketing activities in the airline industry. Social media, live chats, customer communities, email messages and mobile applications are just some of the communication channels that provide valuable and legitimate information on service users. These data represent an important source for developing an effective marketing and purchasing strategy to enhance the overall customer experience.

Modern airline companies wish to differentiate their CRM programmes in a more efficient way, which implies devoting special attention to market segmentation. Value-based segmentation is of particular relevance for modern airline companies, as it helps understanding the profitability of each user. The airline companies can use this criterion to determine which travelers to retain, as well as how to make less valuable travellers more valuable and loyal. Research has shown that SCRM concept implementation by airline companies can contribute to better management of business activities (Route and schedule planning and profitability), as well as the activities related to yield management.

\section{REFERENCES}

Biederman, P. S. (2008). Travel and tourism : an industry primer. Upper Saddle River, NJ: Pearson/Prentice Hall.

Chaffey, D., Chadwick, F. E., Johnston, K., \& Mayer, R., (2006). Internet Marketing. Upper Saddle River, NJ: Prentice Hall.

Chess Media Group (2010). Guide to understanding social CRM. Retrived May 9, 2016 from: http://www.slideshare.net/fred.zimny/chess-media-group-guide-tosocial-crm-2010

Xu, F., Tian, F., Buhalis,D., Weber, J., \& Zhang, H., (2016). Tourists as Mobile Gamers: Gamification for Tourism Marketing. Journal of Travel \& Tourism Marketing, 33(2016). doi:10.1080/10548408.2015.1093999

Kekec M.D., \& Atay L. (2012). Electronic marketing practices at hotels in Turkey and a survey with four and five star hotels. An International Multidisciplinary Journal of Tourism, 7(2), 183-201.

Mangold, W.G., \& Faulds,D.J. (2009). Social media: The new hybrid element of the promotion mix. Business Horizons, 52, 357-365

Mastorakis,G., Trihas, N., Perakakis, E., \& Kopanakis, I., (2015) E-CRM in tourism exploiting emerging information and communication technologies, Anatolia. An International Journal of Tourism and Hospitality Research, 26(1), 32-44. doi:10.1080/13032917.2014 .902767

Milović, B. (2012). Social Media and eCRM as a Prerequisite for Hotel Success. Management Information Systems, 7(3), 26-31.

Morgan, J., Chan, C., \& Mackenzie, J. (2011). An Introduction to Social CRM for the Travel Industry. Retrived May 8, 2016 from http://www.veilleinfotourisme.fr/medias/fichier/introduction-to-socialcrm-for-travel_1334763359868.pdf 
Neises, L. (2013). Social CRM in the Airline Industry: Engaging the Digital Natives. Zürich: LIT.

Russo, X. (2011). Top Reasons for Buying a CRM. Retrieved September 9, 2016 from http://www.softwareshortlist.com/articles/Top_reasons_for_buying_CRM_software.html

Stratos Jet Charters. (2016). Airline Tweet Support. Retrieved September 9, 2016 from https://www.stratosjets.com/airline-tweet-support/

Talkwalker. (2016). Top 40 Airlines Social Media. Retrived June 18, 2016 from http://blog.talkwalker. com/en/top-40-airlines-social-media/
Tussyadiah, I.P., \& Pesonen, J., (2016). Drivers and barriers of peer-to peeraccommodation stay: An exploratory study with American and Finnish travellers. Current Issues in Tourism, 1-18. doi:10.1080/13683500.2016.1 141180

Živković, R., Njeguš, A., Gajić, J., Brdar, I., \& Mijajlović, I. (2015). Upravljanje online zajednicama u hotelijerstvu. Singidunum International Tourism Conference 2015 - SITCON. doi:10.15308/sitcon-2015-133-139. 